\title{
THE CAUSAL FACTORS OF PERIAPICAL AND PULP DISEASE AMONG SENIOR COMMUNITY OF KAGOK COMMUNITY HEALTH CENTER SEMARANG
}

\author{
Sariyem $^{\bowtie 1}$, Bambang Sutomo ${ }^{2}$, Florida Varianti ${ }^{3}$
}

\begin{abstract}
ABSTRAK
Tingginya angka penyakit pulpa dan jaringan periapikal paling banyak diderita kelompok umur 45-60 tahun sebanyak $34 \%$ pada kelompok lanjut usia. Penelitian ini bertujuan untuk mengetahui faktor penyebab penyakit pulpa dan jaringan periapikal pada kelompok lansia di Puskesmas Kagok Semarang.

Sampel dalam penelitian ini 83 orang lansia di kelurahan Wonotingal yang mempunyai riwayat gigi berlubang. Pengambilan data dilakukan dengan pemeriksaan Plak Indeks, Hidrasi saliva, pH Saliva, Viskositas saliva serta menggunakan kuesioner untuk mengetahui faktor perilaku, faktor lingkungan, faktor pelayanan kesehatan dan faktor keturunan.

Hasil penelitian menunjukkan plak indek tertinggi dengan kriteria buruk sebesar 57,8\%, hidrasi saliva tertinggi dengan kriteria rendah sebesar 49,3\%, pH saliva tertinggi dengan kriteria asam sebesar 66,2\%, dan viskositas saliva tertinggi dengan kriteria buruk sebesar 73,4\%. Faktor perilaku lansia dengan kriteria sedang sebesar 66,2\%, faktor lingkungan kriteria sedang sebesar 63,8\%, faktor pelayanan kesehatan dengan kriteria sedang sebesar 57,8\% dan faktor keturunan dengan kriteria sedang sebesar 78,3\%. Hasil uji statistik menunjukkan bahwa hubungan antara variabel pengaruh dan variabel terpengaruh dengan interval koefisien dengan nilai $R$ 0,303 yang menunjukkan tingkat hubungan rendah.
\end{abstract}

Kata kunci: Penyakit pulpa, jaringan periapikal, lansia.

\begin{abstract}
The high rate of pulp disease and periapical tissue suffered most of the age group of 45-60 years as much as $34 \%$ in the elderly group. This study aims to determine the factors causing pulpal disease and periapical tissue in the elderly group at puskesmas Kagok.

The sample in this study were 83 elderly people in Wonotingal subdistrict who had a history of cavities. The data were collected by index plaque, salivary hydration, Saliva $\mathrm{pH}$, salivary viscosity and using a questionnaire to know behavior factor, environmental factor, health service factor and heredity factor.

The results showed the highest index plaque with bad criterion equal to 57,8\%, highest salivary hydration with low criterion equal to 49,3\%, highest salivary $\mathrm{pH}$ with acid criteria equal to $66,2 \%$, highest salivary viscosity with bad criterion equal to 73,4\%. Factors are elderly behavior with medium criterion equal to $66,2 \%$, medium criterion criteria are $63,8 \%$, health service factor with medium criterion equal to $57,8 \%$ and descent factor with medium criterion $78,3 \%$. The results of statistical tests show that the relationship between influence and variable variables affected by confusion interval with a value of $R 0.303$ which indicates the level of low relationship.
\end{abstract}

Key words : Pulp disease and periapical tissue in the elderly

${ }_{1,2)}$ Dosen Jurusan Keperawatan Gigi Poltekkes Kemenkes Semarang

${ }^{3)}$ Mahasiswa Jurusan Keperawatan Gigi Poltekes Kemenkes Semarang

: sariyemjkg@gmail.com 


\section{PENDAHULUAN}

Di Indonesia masalah gigi dan mulut saat ini belum masuk dalam daftar penyakit yang mematikan. Kondisi inilah yang membuat sebagian masyarakat mengesampingkan upaya mencegah bahkan juga mengobati penyakit gigi dan mulut, berbagai masalah bisa mengintai dan dapat menimbulkan penyakit berbahaya mulai dari jantung hingga diabetes (Astuti, 2006).

Gigi berlubang yang tidak dirawat akan menjadi sumber infeksi yang dapat mempengaruhi kondisi organ lainnya,karena bakteri dari gigi berlubang dapat menembus jaringan lebih dalam yang di sebut pulpa gigi yang terdiridari jaringan syaraf, pembuluh darah dan limfe. Bakteri kemudian menghancurkan seluruh pulpa. Keadaan ini memungkinkan terjadinya pembengkakan pada ujung akar berbentuk kantong yang disebut granuloma. Granuloma mengandung jaringan lunak, bakteri dan nanah yang dapat tertekan dalam pembuluh darah sehingga terbawa bagian tubuh yang lain. Jaringan pulpa dapat mengalami peradangan baik bersifat akut maupun kronis hal tersebut akibat adanya iritasi mikroba (bakteri) bermula pada jaringan pulpa kemudian terhadap jaringan sekitar akar (periapikal) (Walton dan Torabinejad, 1998). Penyebaran bakteri juga dapat melalui saluran limfe berhubungan langsung dengan saluran pernafasan dan pencernaan. Penyebaran bakteri dapat menimbulkan penyakit pada mata, hidung, jantung, persendian, ginjal (Mangunprasodjo, 2004).

Penyakit utama gigi dan mulut yang sering ditemukan adalah penyakit mengenai pulpa dan jaringan periapikal. Penyakit pulpa dan kerusakan jaringan periapikal masih menjadi masalah, berdasarkan data dari Departemen Kesehatan RI tahun 2010 dari 10 Penyakit terbesar Rawat Jalan, penyakit pulpa dan periapikal berada pada urutan ke tujuh dengan presentasi 52,95\% dan berdasarkan data dari Dinas Kesehatan Kota Semarang tahun 2009 menunjukkan bahwa penyakit gigi dan mulut menempati urutan
10 besar penyakit yang ada di Puskesmas wilayah kerja Dinas Kesehatan Kota Semarang khususnya penyakit pulpa dan jaringan periapikal menduduki urutan kedua dan penyakit gusi serta jaringan periodontal pada urutan ke tujuh.

Keadaan kesehatan gigi dan mulut di wilayah kerja Puskesmas Kagok, Kecamatan Candisari, Kota Semarang masih sangat memprihatinkan. Laporan data sepuluh besar penyakit gigi dan mulut Puskesmas Kagok menyebutkan penyakit pulpa dan jaringan periapikal selalu masuk dalam urutan pertama. Berdasarkan hasil kunjungan 5 tahun terakir sampai bulan Juni tahun 2012 menunjukan kejadian penyakit pulpa dan jaringan periapikal sebesar $67,43 \%$, kelainan dentofasial dan maloklusi $13,08 \%$, penyakit gusi dan jaringan periodontal $8,96 \%$, karies gigi $2,95 \%$, serta penyakit rongga mulut lainnya $1,89 \%$ dari jumlah seluruh kunjungan ke Poli Gigi Puskesmas Kagok. Tingginya angka penyakit pulpa dan jaringan periapikal paling banyak diderita oleh kelompok umur 45-60 tahun sebanyak 34\% pada kelompok lansia di Puskesmas Kagok.

Tujuan penelitian ini adalah untuk mengetahui gambaran penyakit pulpa dan jaringan periapikal pada kelompok lansia di Puskesmas Kagok dari faktor internal maupun eksternal.

\section{METODE PENELITIAN}

Kegiatan penelitian dilakukan di Kelurahan Wonotingal Semarang dengan kelompok sasaran lansia yang berusia 45-60 tahun. Sampel penelitian 83 orang lansia. Pelaksanaan penelitian ini yaitu pemeriksaan plak indeks, hidrasi saliva, $\mathrm{pH}$ saliva, Viskositas saliva, dan pemberian kuesioner untuk melihat faktor external. Penelitian ini menggunakan uji korelasi bivariat untuk mengukur keeratan hubungan antara hasilhasil dari dua variabel yang berbeda yaitu faktor dari dalam dan faktor dari luar penyebab penyakit pulpa dan jaringan periapikal pada kelompok lansia. 


\section{HASIL DAN PEMBAHASAN}

Tabel 1. Distribusi Frekuensi Hasil Pemeriksaan Plak Indeks PHP-M Pada Lansia

\begin{tabular}{ccr}
\hline Skor & Kriteria & Prosentase \\
\hline 0,0 & Sangat Baik & $0,00 \%$ \\
$0,1-1,7$ & Baik & $6,02 \%$ \\
$1,8-3,4$ & Sedang & $36,14 \%$ \\
$3,5-5,0$ & Buruk & $57,83 \%$ \\
\hline \multicolumn{2}{c}{ Jumlah } & $\mathbf{1 0 0 \%}$ \\
\hline
\end{tabular}

Tabel 2. Hasil pemeriksaan Hidrasi Saliva pada Lansia di Kelurahan Wonotingal

\begin{tabular}{lcc}
\hline Skor & Kriteria & Prosentase \\
\hline$<30$ detik & Tinggi & $2,40 \%$ \\
30-60 detik & Sedang & $48,19 \%$ \\
$>$ 60 detik & Rendah & $49,39 \%$ \\
\hline Jumlah & & $\mathbf{1 0 0 \%}$ \\
\hline
\end{tabular}

Tabel 3. Hasil Pemeriksaan pH Saliva pada Lansia di Kelurahan Wonotingal

\begin{tabular}{ccc}
\hline Kondisi & Kriteria & Prosentase \\
\hline $5,0-5,8$ & Asam & $66,26 \%$ \\
$6,0-6,6$ & Netral & $19,27 \%$ \\
$6,8-7,8$ & Basa & $14,45 \%$ \\
\hline \multicolumn{2}{c}{ Jumlah } & $\mathbf{1 0 0 \%}$ \\
\hline
\end{tabular}

Tabel 4. Hasil Pemeriksaan Visikositas Saliva Pada Lansia di Kelurahan Wonotingal

\begin{tabular}{lcc}
\hline Viskositas & Kriteria Prosentase \\
\hline Bening,cair,tidak berbusa & Baik & $4,81 \%$ \\
Putih berbusa & Sedang & $21,68 \%$ \\
Lengket,putih,berbusa & Buruk & $73,49 \%$ \\
\hline Jumlah & & $\mathbf{1 0 0 \%}$ \\
\hline
\end{tabular}

Tabel 5. Distribusi Frekuensi faktor External Faktor luar penyakit pulpa dan jaringan periapikal

\begin{tabular}{ccccc}
\multirow{2}{*}{ Kriteria } & \multicolumn{4}{c}{ periapikal } \\
\cline { 2 - 5 } & Lingkungan & Perilaku & Yankes & Keturunan \\
\cline { 2 - 5 }$\%$ & $\%$ & $\%$ & $\%$ \\
\hline Baik & 14,45 & 16,86 & 18,08 & 4,81 \\
Sedang & 63,85 & 66,26 & 57,83 & 78,31 \\
Buruk & 21,68 & 16,86 & 24,09 & 16,86 \\
\hline
\end{tabular}

Penelitian ini menggunakan uji korelasi bivariat untuk mengukur keeratan hubungan antara hasil-hasil dari dua variabel yang berbeda yaitu faktor dari dalam dan faktor dari luar penyebab penyakit pulpa dan jaringan periapikal pada kelompok lansia yaitu hubungan antara variabel pengaruh dengan variabel terpengaruh penyebab penyakit pulpa dan jaringan periapikal pada lansia yang di lihat dari sig. (2-tailed). Jika $\mathrm{p}$ $<0,005$, maka Ho di tolak dan Ha di terima.

Tabel 6. Hubungan Antara Variabel Pengaruh dan Variabel Terpengaruh Penyebab Penyakit Pulpa dan Jaringan Periapikal pada Kelompok Lansia di Kelurahan Wonotingal, Kota Semarang

\begin{tabular}{|c|c|c|}
\hline Variabel Pengaruh & p-value & Keterangan \\
\hline \multicolumn{3}{|l|}{ Faktor dari dalam } \\
\hline a. IP PHP-M & 0,100 & Tidak \\
\hline b. Hidrasi saliva & 0,494 & Tidak signifikan \\
\hline c. pH saliva & 0,012 & Signifikan \\
\hline d. Viskositas saliva & 0,001 & Signifikan \\
\hline
\end{tabular}

Faktor dari dalam
a. Perilaku
0,005 Signifikan
b. Lingkungan
0,039 Signifikan
c. Pelayanan kesehatan
0,199 Tidak signifikan
d. Keturunan
0,607 Tidak signifikan

Penelitian ini menggunakan model analisis regresi linier untuk mengetahui seberapa besar pengaruh variabel pengaruh dan variabel terpengaruh antara faktor dari dalam dan faktor dari luar.

Tabel 7. Hasil Uji Regresi Linier Berganda (Tabel Model Summary)

\begin{tabular}{lcc}
\hline \multicolumn{1}{c}{ Variabel } & Nilai R & $\begin{array}{c}\text { Tingkat } \\
\text { Hubungan }\end{array}$ \\
\hline $\begin{array}{l}\text { Hidrasi Saliva } \\
\text { pH Saliva }\end{array}$ & & \\
Viskositas saliva & & \\
Faktor Perilaku & 0,303 & Lemah \\
Faktor Lingkungan & & \\
Faktor Pelayanan kesehatan & & \\
Faktor Keturunan & & \\
\hline
\end{tabular}

Hasil survey di masyarakat kelompok lansia usia 45-60 tahun di Kelurahan Wonotingal Kota Semarang didapatkan hasil faktor-faktor penyebab penyakit pulpa dan jaringan periapikal meliputi 2 faktor yaitu faktor dari dalam dan faktor dari luar yaitu : 
1. Faktor dari dalam penyebab penyakit pulpa dan jaringan periapikal pada lansia

\section{a. Plak}

Hasil pemeriksaan yang dilakukan di kelompok lansia usia 4560 tahun di Kelurahan Wonotingal Kota Semarang menunjukkan bahwa kebersihan gigi dan mulut yang dilihat dari keadaan plak terdapat $57,83 \%$ memiliki plak dengan kriteria buruk. Hal ini menunjukkan keadaan plak responden kurang baik karena perilaku lansia di Kelurahan Wonotingal yang kurang tepat dalam memelihara kesehatan gigi dan mulut. Waktu menyikat gigi pada responden yang tidak menyikat gigi pagi setelah sarapan sebesar $61,44 \%$. Responden tidak menyikat gigi malam hari sebelum tidur dari jawaban kuesioner yang diberikan oleh lansia sebesar $81,92 \%$. Kebanyakan memilih waktu menggosok gigi yang salah yaitu saat mandi sedangkan waktu yang tepat untuk menggosok gigi adalah pagi setelah sarapan dan malam sebelum tidur.

Plak adalah sisa makanan yang sudah bercampur dengan bakteri dan saliva yang melekat erat pada permukaan gigi, plak dapat di bersihkan dengan menyikat gigi secara teratur, plak mengandung bakteri apabila tidak dibersihkan maka akan tetap tinggal di permukaan gigi yang lama kelamaan dapat melarutkan lapisan gigi yang pada akhirnya dapat menyebabkan penyakit pulpa dan jaringan periapikal (Kidd dan Bechal, 1992).

b. pH saliva

Berdasarkan

hasil pemeriksaan yang dilakukan pada 83 lansia di posyandu lansia pada Kelurahan Wonotingal yang merupakan wilayah binaan Puskesmas Kagok, Kota Semarang menunjukkan bahwa sebagian besar responden mempunyai $\mathrm{pH}$ saliva yang asam sebesar 66,26\%. Apabila $\mathrm{pH}$ saliva mencapai $\mathrm{pH}$ kritis yang menyebabkan terjadinya proses demineralisasi jaringan keras gigi. Individu yang mempunyai banyak karies akan mempunyai $\mathrm{pH}$ saliva yang asam (Sundoro, 2005).

\section{c. Hidrasi saliva}

Penyakit pulpa dan jaringan periapikal juga dapat disebabkan oleh hidrasi saliva yang rendah, berdasarkan hasil pemeriksaan yang dilakukan pada 83 responden diperoleh hasil bahwa $2,40 \%$ responden memiliki hidrasi sliva yang normal dan 49,39\% responden memiliki hidrasi saliva rendah. Produksi saliva minimal terjadi pada waktu tidur, karena itu menyikat gigi yang paling penting adalah sebelum tidur karena fungsi protektif saliva juga paling rendah (Sundoro, 2005).

\section{d. Viskositas saliva}

Viskositas juga dapat mempengaruhi terjadinya penyakit pulpa dan jaringan periapikal. Berdasarkan hasil pemeriksaan $73,49 \%$ responden mempunyai viskositas buruk dimana saliva responden sebagian besar dalam keadaan sangat lengket, putih dan berbusa. Selanjutnya 21,68\% responden dengan viskositas saliva sedang dimana saliva responden dalam keadaan putih berbusa (Kidd dan Bechal, 1992).

\section{Faktor external penyebab penyakit pulpa dan jaringan periapikal pada lansia}

\section{a. Faktor Perilaku}

Berdasarkan hasil survey yang dilakukan pada posyandu lansia dalam Kelurahan Wonotingal di wilayah binaan Puskesmas Kagok Kota Semarang dimana menunjukkan 55 responden $(66,26 \%)$ memiliki perilaku dengan kriteria sedang dan 14 
responden $(16,86 \%)$ memiliki perilaku dengan kriteria buruk. Dapat dilihat dari jawaban yang salah tertinggi responden pada semua pertanyaan yaitu dimana masih banyak responden yang menjawab salah dalam waktu yang tepat untuk menggosok gigi yaitu sebanyak 51 responden $(61,44 \%)$ tidak menggosok gigi pagi setelah sarapan melainkan pada saat mandi dan hanya 32 responden $(38,55 \%)$ yang menyikat gigi setelah sarapan, pada malam hari juga masih banyak responden yang tidak menggosok gigi malam sebelum tidur sebanyak 68 responden $(81,92 \%)$ melainkan pada saat mandi sore dan responden yang menggosok gigi malam sebelum tidur hanya 15 responden $(18,07 \%)$. Pengetahuan responden juga masih dalam kriteria kurang, masih ada responden tidak tahu penyebab dari gigi berlubang dan responden juga berpendapat bahwa tusuk gigi baik digunakan untuk membersihkan sisa makanan setelah selesai makan dengan 63 responden $(75,90 \%)$.

Berdasarkan teori Green perilaku yang salah ini disebabkan oleh pengetahuan dari para lansia di Kelurahan Wonotingal wilayah kerja Puskesmas Kagok Kota Semarang yang rendah tentang kesehatan gigi dan mulut sehingga menjadi penyebab utama perilaku masyarakat lansia salah dalam pemeliharaan kesehatan gigi dan mulut. Sedangkan perilaku menyikat gigi adalah segala bentuk dan interaksi individu dengan lingkungan, khususnya yang menyangkut pengetahuan, sikap dan psikomotorik tentang kesehatan terutama dalam hal menyikat, sehingga dalam proses interaksi tersebut diperlukan pengetahuan terutama tentang perilaku menyikat gigi, namun dalam prakteknya tidak dapat dilaksanakan karena diantaranya merupakan faktor kebiasaan (Notoatmojo, 2007).

\section{b. Faktor Lingkungan}

Berdasarkan hasil survey yang dilakukan pada masyarakat di kelurahan Wonotingal wilayah kerja Puskesmas Kagok dimana 53 responden $(63,85 \%)$ memiliki keadaan lingkungan dengan kriteria sedang dan 18 responden $(21,68 \%)$ memiliki lingkungan dengan kriteria buruk, hal yang paling menonjol terlihat dari faktor lingkungan penyebab penyakit pulpa dan jaringan periapikal adalah penghasilan masyarakat yang masih minim dimana 54 responden $(65,65)$ tidak mempunyai pekerjaan tetap dan sebanyak 43 responden $(51,80 \%)$ berpenghasilan dibawah UMR Kota Semarang serta 40 responden $(48,19 \%)$ berpenghasilan sudah sesuai UMR. Selain faktor penghasilan masih terdapat 62 responden $(74,69 \%)$ mengobati sakit giginya dengan membeli obat-obatan di luar dan 46 responden $\quad(55,42 \%) \quad$ masih menggunakan obat tradisional untuk mengobati sakit gigi, ada 48 responden $(57,83 \%)$ lebih memilih mengkonsumsi makanan instan dibandingkan dengan makanan olahan sendiri 35 responden $(42,16 \%)$.

Lingkungan adalah sesuatu yang berada di luar atau di sekitar mahluk hidup. Faktor lingkungan merupakan salah satu faktor yang di pandang sebagai beban dari pada sebagai sumber daya. Dari aspek ekonomi orang yang sudah tidak berproduktif lagi hidupnya ditopang oleh generasi yang lebih muda. Pendapatannya juga menurun dibandingkan pada saat usia produktif, hal ini juga akan mempengaruhi derajat kesehatan (Notoatmodjo, 2007).

Selain faktor ekonomi, lingkungan sosial juga mempengaruhi terjadinya penyakit pulpa dan jaringan periapikal seperti kebiasaan mengkonsumsi makanan instan serta kebiasaan menggobati sendiri penyakit 
pulpa dan jaringan periapikal dengan membeli obat di luar.

\section{c. Faktor Pelayanan Kesehatan}

Berdasarkan hasil survey yang dilakukan pada kelompok lansia di Kelurahan Wonotingal wilayah kerja Puskesmas Kagok yang dilihat dari faktor pelayanan kesehatan dengan kriteria sedang sebesar 48 responden $(57,83 \%)$ dan pelayanan kesehatan dengan kriteria buruk sebesar 20 responden $(24,09 \%)$ berdasarkan jawaban kuesioner yang paling dominan menunjukkan bahwa 54 responden $(65,06 \%)$ menjawab belum pernah mendapatkan penyuluhan tentang kesehatan gigi dan mulut oleh petugas kesehatan di wilayah tempat tinggal mereka dan 50 responden $(60,24 \%)$ menjawab tidak bisa menjangkau biaya perawatan gigi yang ada di puskesmas.

\begin{tabular}{lrr}
\multicolumn{2}{c}{ Meningkatnya } & kasus \\
kehilangan gigi secara tajam, & usia \\
berdasarkan kelompok & menggambarkan bahwa upaya \\
pelayanan kesehatan gigi untuk
\end{tabular}
mempertahankan gigi selama mungkin dalam rongga mulut belum terlaksana dengan baik (Barnes dan Walls, 2006). Demikian pula penanganan penyakit gigi dan mulut, umumnya cenderung hanya penyakit gigi yang belum bersifat komperhensif dan holistik yaitu meliputi promotif, preventif, kuratif dan rehabilitatif yang ditujukan pada semua golongan umur (PDGI, 2011). Umumnya dokter gigi hanya menerima dan mengobati pasien yang datang berobat gigi, sedangkan upaya promotif dan preventif masih kurang diperhatikan.

\section{d. FaktorKeturunan}

Berdasarkan hasil survey yang dilakukan pada kelompok lansia di Kelurahan Wonotingal kota Semarang, 65 responden $(78,31 \%)$ memiliki faktor keturunan penyebab penyakit pulpa dan jaringan periapikal dengan kriteria sedang dan 14 responden $(16,86 \%)$ memiliki faktor keturunan penyebab penyakit pulpa dan jaringan periapikal dengan kriteria buruk, dari faktor keturunan yang paling mempengaruhi terjadinya penyakit pulpa dan jaringan periapikal berdasarkan hasil kuesioner adalah keadaan gigi responden yang rapuh sebanyak 56 responden $\quad(67,64 \%)$ serta dipengaruhi oleh kandungan air ludah yang tidak banyak dan tidak encer yang dialami oleh lansia itu sendiri.

Berdasarkan hasil pemeriksaan dari keempat faktor dari luar penyebab penyakit pulpa dan jaringan periapikal bila dikaitkan satu sama lain adalah lansia yang memiliki perilaku yang kurang baik diakibatkan oleh kurangnya kesadaran lansia tentang pentingnya menjaga kesehatan gigi dan mulut terutama waktu yang tepat dalam menyikat gigi dan kebiasaan menggunakan tusuk gigi setelah makan, selain itu juga didukung oleh faktor lingkungan dimana dari segi ekonomi lansia masih kurang sehingga ada beberapa masyarakat yang lebih mementingkan kebutuhan lain dari pada harus menjaga kebersihan gigi dan mulutnya, selain itu faktor pelayanan kesehatan, dari segi tenaga kesehatan gigi dan mulut harus lebih sering memberikan penyuluhan tentang kesehatan gigi kepada lansia agar lansia sadar akan pentingnya kesehatan gigi dan mulut sehingga salah satu penyakit gigi dan mulut yaitu penyakit pulpa dan jaringan periapikal bisa di hindari sejak dini, selain itu faktor keturunan juga mempengaruhi seperti keadaan gigi yang rapuh dimana lansia yang sudah mengetahui bahwa keadaan gigi mereka rapuh masih tetap tidak 
peduli dengan kesehatan giginya karena didukung faktor perilaku dan lingkungan ekonomi sehingga keadaan gigi yang rapuh tetap dibiarkan.

\section{KESIMPULAN}

1. Faktor-faktor eksternal penyebab penyakit pulpa dan jaringan periapikal meliputi :

a. Faktor perilaku yang menyebabkan terjadinya penyakit pulpa dan jaringan periapikal yaitu tidak menggosok gigi pagi setelah sarapan $(61,44 \%)$ dan tidak menggosok gigi malam sebelum tidur $(81,92 \%)$.

b. Faktor lingkungan yang menyebabkan penyakit pulpa dan jaringan periapikal yaitu sebesar $65 \%$ lansia tidak mempunyai pekerjaan tetap.

c. Faktor pelayanan kesehatan yang menyebabkan penyakit pulpa dan jaringan periapikal sebesar $65 \%$ dimana lansia tidak pernah mendapatkan penyuluhan tentang kesehatan gigi dan mulut dari tenaga kesehatan.

d. Faktor keturunan yang menyebabkan resiko terjadinya penyakit pulpa dan jaringan periapikal yaitu sebesar $67,46 \%$ yaitu keadaan gigi rapuh.

2. Faktor-faktor interrnal penyebab penyakit pulpa dan jaringan periapikal meliputi :

a. Keadaan plak pada responden prosentase paling tinggi dengan kriteria buruk sebesar 57,83\%, karena rendahnya tingkat pengetahuan dan sikap terhadap hidup sehat sangat berpengaruh terhadap perilaku masyarakat lansia sehingga tingkat kebersihan gigi dan mulut responden dalam kriteria buruk yang mana apabila dibiarkan dan tidak ditindak lanjuti akan berakibat pada tingginya angka kesakitan gigi yaitu penyakit pulpa dan jaringan periapikal. b. Keadaan saliva dalam hal ini $\mathrm{pH}$ saliva dimana pada masyarakat lansia di Kelurahan Wonotingal masih banyak yang asam sebesar 66,26\% dan yang netral hanya $19,27 \%$. Selain itu keadaan hidrasi saliva yang rendah sebanyak 49,39\% dan yang sedang $48,19 \%$, normalnya cuma $1,20 \%$ dan viskositas saliva yang buruk sebanyak $73,49 \%$ yang baik dan yang baik hanya $4,81 \%$ dikarenakan produksi saliva dan keadaan kekentalan saliva dan menyebabkan akumulasi plak yang banyak sehingga akan menimbulkan terjadinya karies yang berlanjut ke penyakit pulpa dan jaringan periapikal.

\section{SARAN}

1. Masyarakat lansia diharapkan untuk menyikat gigi secara rutin dan teratur 2 kali sehari, pagi setelah sarapan dan malam sebelum tidur

2. Masyarakat lansia diharapkan dapat memeriksakan kesehatan gigi dan mulutnya secara rutin setiap 6 bulan sekali dan melakukan penambalan pada gigi yang berlubang sehingga dapat menghindari terjadinya penyakit pulpa dan jaringan periapikal.

3. Menambah pengetahuan masyarakat tentang kesehatan gigi dan mulut melalui :

a. Penyuluhan tentang pemeliharaan kesehatan gigi dan mulut disertai dengan pemberian leaflet cara menyikat gigi

b. Penyuluhan tentang akibat gigi berlubang disertai dengan pemberian leaflet akibat gigi berlubang

4. Agar sekresi dan viskositas saliva normal di sarankan kepada lansia untuk lebih banyak mengkonsumsi air minum. 


\section{DAFTAR PUSTAKA}

Anonim.2010, Manajemen Perilaku Kesehatan Gigi dan mulut, http://managemen-perilakukesehatan-gigi-mulut-masyarakat/, diakses pada tanggal 08 Desember 2012.

Anonim.2011, Hubungan Pendidikan Penyikatan Gigi dengan Tingkat Kebersihan,http://resources.unpad.ac. id/unpadcontent/uploads/publikasidos en/Hubungan\%20Pendidikan\%20Pen yikatan\%20Gigi\%20dg\%20Tingkat\% 20Kebersihan\%20Gi.pdf diakses pada tanggal 12-02-2013 pukul $23: 42$.

Astuti, T., 2006, 89\% Anak Derita Penyakit Gigi dan Mulut, http://www.Jurnalnet.com/konten.php ?nama=beritautama\&topic $=7 \& \mathrm{id}=51$ 5 diakses tanggal 06 Desember 2012.

Barnes I. E., dan Walls A., 2006, Perawatan Gigi Terpadu untuk Lansia, EGC, Jakarta, 39-41,287-290.

Bratthal D., Petersson GH, Stjernsward JR, 2004, Cariogram manual. A new and interactive way of illustrating the interaction of factors contributing to thedevelopment of dental caries. http://www.db.od.mah.se/car/cariogra $\mathrm{m} /$ cariograminfo.html diakses pada tanggal 9 Februari 2013.

Fahlevi, R., 2008, Periapikal Granuloma, http://userbrains.com/2008/10/20/peri apikal-granuloma/, diakses tanggal 06 Desember 2012.

Kidd, E.A.M dan Bechal, S.J., 1992, DasarDasar Penyakit dan penanggulangannya, EGC, Jakarta, 3-10, 92.
Kidd, E.A.M., Smith, B.G.N., Pickard, H.M., 2002, Manual Konsevasi Restoratif (Pickards,s manual of operative dentistry), Widya Medika, Jakarta, 35.

Mangoenprasodjo, 2004, Gigi Sehat Mulut Terjaga, Think Fresh, Jogjakarta, 74.

Notoatmojo, S., 2003, Ilmu Kesehatan Masyarakat Prinsip-Prinsip Dasar, Rineka Cipta, Jakarta, 124 dan 146. Kesehatan, Rineka Cipta, Jakarta, 46 dan 49.

, 2007, Kesehatan Masyarakat Ilmu dan Seni, Rineka Cipta, Jakarta, 167.

PDGI, 2011, Kebijakan dan Pengembangan Kesehatan Gigi dan Muluthttp://www.pdgi.or.id/artikel/de tail/sambutan-menteri-kesehatanrepublik-indonesia-pada-peringatanbulan-kesehatan-gigi-nasional, 2011. Diakses tanggal 23 Februari 2013.

Pratiwi, D., 2007, Gigi Sehat, Merawat Gigi Sehari Hari, Kompas, Jakarta, 23-27.

Samanayake, 2002, Essential Microbilogy for Dentistry, Secon Edition, Harcourt Publishers, Churchill Livingstone, London, 218-220.

Schuurs, A. H. B., 1992, Patologi Gigi Geligi Kelainan Jaringan Keras Gigi, Jogjakarta, Gajah Mada University Press.

Suwelo, 1992, Karies Gigi pada Anak dengan Pelbagai Faktor, EGC, Jakarta.

Sundoro, E.H, 2005, Serba-Serbi Ilmu Konservasi Gigi, IU-Press, Jakarta, 58-65. 
Syafii,I., 2012, Pemeriksaan-Saliva-dan-

Plak-untuk-Menentukan-Faktor-

Resiko- Karies, http://tulisandoktergigimuda. Diakses tanggal 23 Februari 2013.

Tarigan, R., 2006, Perawatan Pulpa Gigi (Endodonti), EGC, Jakarta, 23-37.

Walton, R. dan Torabinejad, M., 1998, Prinsip dan Praktek Ilmu Endodonsi, EGC, Jakarta, 33-35,40-66. 